\section{Field Evaluation of Watermelon Grown on Paper-Polymerized Vegetable Oil Mulches}

\author{
Randal L. Shogren ${ }^{1}$ \\ Plant Polymer Research Unit, National Center for Agricultural Utilization \\ Research, U.S. Department of Agriculture, Agricultural Research Service, \\ 1815 North University Street, Peoria, IL 61604
}

Robert C. Hochmuth ${ }^{2}$

University of Florida, Institutes of Food and Agricultural Sciences, North Florida Research and Education Center-Suwannee Valley, 7580 County Road 136, Live Oak, FL 32060

Additional index words. soybean, linseed, kraft, biodegradable, fruit, plastic

\begin{abstract}
Biodegradable mulches made from kraft paper coated with polymerized (cured) vegetable oils were compared to black polyethylene mulches for promoting the growth of watermelon in northern Florida. Data from three spring growing seasons have been collected. Yields of watermelon planted on paper-soy oil and paper-linseed oil mulches were similar to those obtained for the control polyethylene mulches. This was the case where the paper-oil was cured before field application as well as when the paper-oil was applied to the field wet and curing took place in situ. Paper-oil mulches containing carbon black effectively blocked nutsedge growth, while nutsedge pierced and grew through the black polyethylene mulch. Degradation of the buried tucks were more rapid initially for paper-soy oil than paper-linseed oil mulch, but both lasted long enough to hold the mulch in place until spring harvests $(\approx 2.5$ months). In conclusion, paper coated with polymerized vegetable oil appears to be an effective substitute for polyethylene mulch for growing watermelon in Florida, although drawbacks include messiness in handling oily paper, slower application speeds, higher initial costs than polyethylene, and variability in rates of curing and degradation depending on soil and weather conditions.
\end{abstract}

It is well known that plastic mulch film increases yields of many vegetables and fruits, especially yields early in the season when prices tend to be higher, most likely by inhibiting weed growth, increasing soil temperature and moisture and reducing pest infestations (LeClaire, 2002; Schut, 2001). Recently, colored and reflective mulches have been developed to suit needs of individual crops and locations. As a result, most vegetables are now grown on plastic (polyethylene) mulch and use has reached $\approx 130$ million $\mathrm{kg} \cdot \mathrm{year}^{-1}$ in the U.S. alone.

However, the removal and disposal of polyethylene mulch from the fields after harvest is difficult and expensive $(\approx 250 / \mathrm{ha})$. Much of this is improperly disposed of by burning or burying leading to environmental and health problems. Disposal in landfills can be problematic due to pesticide residues in plastic mulches. Recycling is difficult due to the amount of dirt on the plastic and some degradation in polyethylene molecular weight

Received for publication 14 Oct. 2003. Accepted for publication 24 Mar. 2004. I thank Elizabeth Krietemeyer for help in preparing the mulches. Product names are necessary to report factually on available data; however the USDA neither guarantees nor warrants the standard of the product, and the use of the name USDA implies no approval of the product to the exclusion of others that may also be suitable.

${ }^{1}$ To whom reprint requests should be addressed; e-mailshogrerl@ncaur.usda.gov. and strength. Also, residues of black plastic in some harvested crops such as cotton or pulpwood make the finished product unacceptable. Thus, a biodegradable mulch which could be tilled into the field and fully biodegrade would be desirable.

Tar-coated paper mulches began to be used in the late 1800 s, long before polyethylene was available (Rivise, 1929). Paper alone degrades too quickly and loses most if its strength when wet so paper was coated to seal out water and protect the paper from microbial action. Such mulches were very effective in increasing the yields of a variety of fruits and vegetables, though the use of tar now would probably be Paper mulches were later replaced by cheaper and tougher polyethylene.

Recently, paper mulches have begun to attract more attention since they are biodegradable and are made from a renewable resource rather than petroleum. Yields of tomatoes (Everett, 1972; Vandenberg and Tiessen, 1972) and strawberries (Albregts and Howard, 1972) were similar for polyethylene coated paper and polyethylene film but were somewhat lower for wax coated paper (Vandenberg and Tiessen, 1972). Recently, Rangarajan (2000) found that melon yields and soil temperatures decreased in the order: black polyester coated paper $=$ black polyethylene $>$ black paper $=$ wax coated black paper $>$ bare ground. Uncoated paper degraded at the soil line within 4 to 5 weeks while the wax coating extended the lifetime to $>6$ weeks considered environmentally unacceptable. for some replications. Paper coated with the biodegradable polyester was intact at the end of the experiment. Brault et al. (2002a, 2002b) found similar weed control and yields of lettuce for paper coated with latex or biodegradable polymer and polyethylene mulch. Olsen and Gounder (2001) found slightly higher soil temperatures for polyethylene and biodegradable polymer mulches than paper but yields of peppers were similar for all three mulches. Similar yields of peppers (Hochmuth and Hochmuth, 1994) and tomatoes (Anderson et al., 1995) were also found for paper and polyethylene mulches. In the latter study, paper was soaked in soybean oil and this slowed the degradation of the paper. The advantage of using soybean or other vegetable oil as a coating is low cost and wide availability.

Previous work by Shogren $(1999,2000)$ has shown that coating kraft paper with polymerized vegetable oil resins increases wet strength and decreases the rate of biodegradation (measured by weight loss) in soil. Half lives of the coated paper in soil increased from 2 weeks for uncoated paper to 4.5 to 12 weeks for resin coated papers, depending on coating type and amount. It was postulated that the oilbased coating serves as a temporary barrier to water and microorganisms thus protecting the underlying cellulose fiber network from degradation. In this study, we have compared the performance of paper-polymerized oil mulches versus a standard black polyethylene control for raising watermelon at an experimental farm in northern Florida. The effects of coating type, amount, method of polymerization and added color and preservative on ease of field application, visual degradation rates, weed growth, and crop yields were studied.

\section{Materials and Methods}

Materials. Brown kraft paper was nominal $40 \mathrm{lb}$ (per $280 \mathrm{~m}^{2}$ ) with a width of $1.22 \mathrm{~m}$. A $100 \%$ recycled grade (Carter Paper, Peoria, Ill.) was used for 2000 trials while a virgin grade (Box Packaging, Addison, Ill.) was used for the 2001 and 2002 years. Soybean oil was refined food grade from local groceries or Alnoroil (Valley Stream, N.Y.). Raw linseed oil was from Cargill (Wayzata, Minn.). Cobalt 2-ethylhexanoate solution in mineral spirits was from Pfaltz\&Bauer and Aldrich. Carbon black was from Fisher. Zinc oxide powder $(<1 \mu \mathrm{m})$ and other chemicals were from Aldrich. Zinc hexaborate (98\%) was from Alfa Aesar. Black polyethylene mulch was 0.6-mil high density polyethylene film from Sonoco (Hartsville, S.C.).

Preparation of coated paper mulch. Vegetable oils were charged into a plastic bucket or aluminum pot equipped with an air stirrer. The polymerization catalyst (cobalt octoate, to give $0.02 \%$ Co by weight of oil) was added followed by vigorous stirring for $10 \mathrm{~min}$. In some cases, carbon black $(0.8 \%$ to $1.5 \%)$ and preservatives were also added with stirring. The carbon black was dispersed into a portion of the oil using a Waring blender on high for 1 $\min$. Three different preservatives were used: 1) a mix of propionic acid $(0.5 \%)$, octanoic 
acid $(0.5 \%)$, lauric acid $(0.5 \%)$, benzoic acid $(0.5 \%)$, salicylic acid $(0.5 \%)$ and cinnamaldehyde $(0.5 \%), 2$ ) zinc oxide (3\% to $5 \%)$, and 3 ) zinc borate $(5 \%)$.

For the year 2000 study, the paper was unrolled outside and soybean oil-catalyst was applied to the paper using brushes and flat velour pads. The coated paper was held to the ground with steel fence posts and polymerization was allowed to occur for $3 \mathrm{~d}$. After curing, the coated paper was rather sticky and thus was dusted with corn starch to prevent sticking of the layers after rolling. Coating weight was about $100 \%$ of paper weight.

For the 2001 and 2002 studies, a simple coating machine was designed and built in order to semi-automate coating and rolling tasks. This consisted of a stainless steel table with supply and motorized take-up rolls on the lower shelf and a flat aluminum sheet on the top shelf for coating. Oil coatings were dripped onto the paper using separatory funnels and were spread either using a paint roller or a neoprene rubber blade clamped between 2 aluminum bars. For the 2001 study, the paint roller method was used and this gave a heavy $(\approx 100 \%$ add on) coating in excess of paper saturation. In an effort to reduce messiness associated with excess oil, paper was coated on both sides using the rubber blade in the 2002 study. This gave an oil add-on of $75 \%$ to $82 \%$ based on paper weight. Mulch rolls were sealed in double polyethylene bags (to avoid premature oxidation-polymerization and chance of fire) and cardboard boxes for shipping.

Field testing. Studies were conducted at Live Oak, Fla., on Lakeland fine sand. Soil was prepared by plowing and discing or rototilling. Soils in the area were infested with low to moderate amounts of yellow nutsedge (Cyperus esculentus L.) Beds were formed on $2.29 \mathrm{~m}$ centers with each bed $0.61 \mathrm{~m}$ wide at the top and $0.15 \mathrm{~m}$ tall. Beds were fertilized with 560 $\mathrm{kg} \cdot \mathrm{ha}^{-1}$ of $13-4-13\left(\mathrm{~N}-\mathrm{P}_{2} \mathrm{O}_{5}-\mathrm{K}_{2} \mathrm{O}\right)$ and then were formed with a bed press. Mulches were applied to the beds with a Kennco mechanical mulch application machine. Plots were 9.1 or $12.1 \mathrm{~m}$ long and each treatment was replicated four times. Plots were arranged in a randomized compete block design. Drip irrigation tape was Robert's RoDrip tape with an 8 mil wall thickness and emitters spaced $0.30 \mathrm{~m}$ apart and was rated at $2.9 \mathrm{~L} \cdot \mathrm{h}^{-1} \cdot \mathrm{m}^{-1}$. $\mathrm{N}$ and $\mathrm{K}_{2} \mathrm{O}$ were added weekly to give rates for the season of 168 $\mathrm{kg} \cdot \mathrm{ha}^{-1}$ of each. For the 2000 study, one-half of each plot was fumigated with a 67 methyl bromide : 33 chloropicrin mixture at a rate of $450 \mathrm{~kg} /$ treated hectare. Watermelon were placed in a single row on each bed with 0.91 $\mathrm{m}$ between plants in a row. Transplants were planted with a mechanical-aid transplanter water-wheel and water was applied with each transplant for aid in transplant establishment. Plant varieties, dates of planting and harvesting are shown in Table 1. Recordings were made of soil temperature at the $10 \mathrm{~cm}$ depth in the beds on 27 Mar. 2000. Mulch degradation at the soil line was evaluated visually using a five point scale: 1) no visible sign of degradation, 2) mulch beginning to soften but still intact, 3) initial degradation visible with small tears or holes in mulch, 4) significant degradation of mulch, nearly $50 \%$ of tuck area degraded, some detachment of paper from buried tuck, and 5) nearly $100 \%$ of buried tuck area degraded, pieces of mulch cannot be separated from soil in tuck area, mulch on top of bed detached from tuck area. All data were analyzed by analysis of variance and means were compared using Duncan's multiple range test.

\section{Results and Discussion}

Paper mulch application was considered acceptable with minimal tearing although the speed used for the paper $\left(3.2 \mathrm{~km} \cdot \mathrm{h}^{-1}\right)$ was less than for the plastic $\left(4.8 \mathrm{~km} \cdot \mathrm{h}^{-1}\right)$. Holes punched in the mulch by the mechanical transplanter tended to tear an additional 2.5 to $5.0 \mathrm{~cm}$. The paper mulches laid tightly to the raised beds and resulted in acceptable mulch beds.

The mulch used for the 2000 trial was brown but allowed some light through the paper since no carbon black was used. Soil temperatures as measured on 27 Mar. (Table 2) were similar for the coated paper and black polyethylene mulch. Weeds grew under the nonfumigated plots of both mulches and thus pushed the mulch up somewhat. Fumigation eliminated weeds from these plots early in the season. As shown in Table 2, watermelon yields were similar for the coated paper and polyethylene mulches. These yields were lower than normal for the area due to severe crow damage. The yields and average fruit weights of the fumigated plots tended to be slightly higher, but these differences were not significant. The soybean oil coated paper mulch showed initial signs of degradation (rating 3 ) after $52 \mathrm{~d}$ and maintained its integrity until harvest (76 d).

Table 1. Watermelon variety and mulching, planting, and harvesting dates.

\begin{tabular}{lllll}
\hline Season & Variety & Mulch application date & Transplant date & Harvest date \\
\hline Spring 2000 & Royal Sweet & 16 March & 23 March & 31 May \\
Spring 2001 & Mardi Gras & 28 March & 29 March & 8 June \\
Spring 2002 & Mardi Gras & 28 March & 28 March & 4 and 12 June \\
\hline
\end{tabular}

Table 2. Effect of fumigation and mulch type on yield, fruit size of 'Royal Sweet' watermelon, and soil temperature in 2000.

\begin{tabular}{llccc}
\hline $\begin{array}{l}\text { Main } \\
\text { effects }\end{array}$ & \multicolumn{2}{c}{ Total marketable yieldAvg fruit } & $\begin{array}{c}\text { Soil temp } \\
\text { wt }(\mathrm{kg})\end{array}$ & $\left({ }^{\circ} \mathrm{C}\right)$ \\
\cline { 2 - 5 }$(\mathrm{no} . / \mathrm{ha})$ & $6,030 \mathrm{a}^{y}$ & $35,600 \mathrm{a}$ & $5.9 \mathrm{a}$ & $33 \mathrm{a}$ \\
\hline Paper/SO & $5,410 \mathrm{a}$ & $34,100 \mathrm{a}$ & $6.4 \mathrm{a}$ & $32 \mathrm{a}$ \\
Polyethylene & $5,730 \mathrm{a}$ & $39,500 \mathrm{a}$ & $6.8 \mathrm{a}$ & $33 \mathrm{a}$ \\
Fumigation & $5,680 \mathrm{a}$ & $30,200 \mathrm{a}$ & $5.4 \mathrm{a}$ & $32 \mathrm{a}$ \\
\hline
\end{tabular}

${ }^{2} \mathrm{SO}=$ soybean oil with cobalt 2-ethylhexanoate $(0.02 \% \mathrm{Co})$.

${ }^{y}$ Values within a column having the same letter are not significantly different $(p<0.05)$.

Table 3. Effect of mulch type on yield, fruit size of Mardi Gras watermelon and nutsedge growth in 2001.

\begin{tabular}{|c|c|c|c|c|c|}
\hline \multirow{2}{*}{$\begin{array}{l}\text { Mulch } \\
\text { type }\end{array}$} & \multicolumn{2}{|c|}{ Total marketable yield } & \multirow{2}{*}{$\begin{array}{l}\text { Avg fruit } \\
\text { wt (kg) }\end{array}$} & \multicolumn{2}{|c|}{$\begin{array}{l}\text { Yellow nutsedge } \\
\text { counts }\left(\text { no. } / \mathrm{m}^{2}\right)\end{array}$} \\
\hline & (no./ha) & $\left(\mathrm{kg} \cdot \mathrm{ha}^{-1}\right)$ & & 18 Apr. & 8 May \\
\hline Paper/LO ${ }^{z}$ & $7,360 \mathrm{a}$ & $69,000 \mathrm{a}$ & $9.5 \mathrm{a}$ & $0 \mathrm{a}$ & $11 \mathrm{a}$ \\
\hline Paper/LO+PM ${ }^{y}$ & $8,150 \mathrm{a}$ & $74,500 \mathrm{a}$ & $9.1 \mathrm{a}$ & $0 \mathrm{a}$ & $11 \mathrm{a}$ \\
\hline Paper/SO ${ }^{x}$ & $7,090 \mathrm{a}$ & $65,500 \mathrm{a}$ & $9.1 \mathrm{a}$ & $0 \mathrm{a}$ & $11 \mathrm{a}$ \\
\hline Paper/SO+PM & $7,000 \mathrm{a}$ & $63,300 \mathrm{a}$ & $9.1 \mathrm{a}$ & $0 \mathrm{a}$ & $11 \mathrm{a}$ \\
\hline Polyethylene & $6,720 \mathrm{a}$ & $61,600 \mathrm{a}$ & $9.1 \mathrm{a}$ & $110 \mathrm{~b}$ & $120 \mathrm{~b}$ \\
\hline
\end{tabular}

${ }^{2} \mathrm{LO}=$ soybean oil with cobalt 2-ethylhexanoate $(0.02 \% \mathrm{Co})$, carbon black $(0.8 \%)$.

y $\mathrm{PM}=$ preservative mix: (see text).

${ }^{\mathrm{x}} \mathrm{SO}=$ soybean oil with cobalt 2-ethylhexanoate $(0.02 \% \mathrm{Co})$, carbon black $(0.8 \%)$. 
held the mulch in place so that further mulch degradation which might cause detachment at the soil line was not critical. Paper mulches containing linseed oil showed less degradation (rating 2) after $54 \mathrm{~d}$ than mulches made with soybean oil (rating 3 ). The slower rate of biodegradation of linseed than soybean oil in soil has been observed previously (Shogren, 2000) and is thought to be due to the greater number of double bonds and hence cross-linking density for linseed oil. The addition of the preservative mix consisting of various organic acids and aldehydes had no significant effect on degradation rates. Since degradation seemed to occur at similar rates in the 2000 and 2001 studies, this suggests that it is not necessary to cure the paper-oil before application and that sufficient air reaches the buried tuck area to cause polymerization of the oil.

Yields of watermelon and nutsedge popula-

tions for the 2002 trial are shown in Table 5. In this trial, coated paper mulches were wiped with a rubber blade to minimize surface oiliness and zinc compounds were tested as preservatives. There were no significant differences in early or total yield between the coated paper and polyethylene mulches. Total marketable yield was in the range of 55 to $85,000 \mathrm{~kg} \cdot \mathrm{ha}^{-1}$, which is considered a good yield for this area. No nutsedge pierced the paper mulches for the first $60 \mathrm{~d}$ of the trial while a small number were able to grow through the polyethylene mulch. Nutsedge populations were low in the plot area. Similar to the 2001 study, nutsedge sprouted under the paper mulches, but could not grow further.

Degradation ratings for the different mulches in the 2002 trial as a function of time after application are shown in Table 6. Degradation of the coated paper mulches

Table 4. Degradation ratings of mulches just below soil line of buried tuck for 2001 trial.

\begin{tabular}{lcccc}
\hline \multirow{2}{*}{$\begin{array}{l}\text { Mulch } \\
\text { type }\end{array}$} & \multicolumn{4}{c}{$\begin{array}{c}\text { Mulch degradation rating } \\
\text { (days after application) }\end{array}$} \\
\cline { 2 - 5 } & 18 & 40 & 54 & 95 \\
\hline Paper/LO & $1.0 \mathrm{a}$ & $1.5 \mathrm{a}$ & $2.0 \mathrm{a}$ & $4.0 \mathrm{a}$ \\
Paper/LO/PM & $1.0 \mathrm{a}$ & $1.5 \mathrm{a}$ & $2.0 \mathrm{a}$ & $4.0 \mathrm{a}$ \\
Paper/SO & $2.0 \mathrm{~b}$ & $3.0 \mathrm{~b}$ & $3.0 \mathrm{~b}$ & $4.0 \mathrm{a}$ \\
Paper/SO/PM & $2.0 \mathrm{~b}$ & $3.0 \mathrm{~b}$ & $3.0 \mathrm{~b}$ & $4.0 \mathrm{a}$ \\
Polyethylene & $1.0 \mathrm{a}$ & $1.0 \mathrm{c}$ & $1.0 \mathrm{c}$ & $1.0 \mathrm{~b}$ \\
\hline
\end{tabular}

${ }^{2}$ Rating scale: 1 = no visible sign of degradation, $2=$ mulch beginning to soften but still intact, $3=$ initial degradation visible with small tears or holes in mulch, 4 = significant degradation of mulch, nearly $50 \%$ of tuck area degraded, some detachment of paper from buried tuck, $5=$ nearly $100 \%$ of buried tuck area degraded, pieces of mulch cannot be separated from soil in tuck area, mulch on top of bed detached from tuck area.

${ }^{y} \mathrm{LO}=$ soybean oil with cobalt 2-ethylhexanoate $(0.02 \% \mathrm{Co})$, carbon black $(0.8 \%)$.

${ }^{x} \mathrm{PM}=$ preservative mix: (see text).

${ }^{\mathrm{w}} \mathrm{SO}=$ soybean oil with cobalt 2 -ethylhexanoate $(0.02 \% \mathrm{Co})$, carbon black $(0.8 \%)$.

Table 5. Effect of mulch type on early and total watermelon yield and nutsedge populations for 2002 trial.

\begin{tabular}{|c|c|c|c|c|c|c|c|}
\hline \multirow{3}{*}{$\begin{array}{l}\text { Mulch } \\
\text { type }\end{array}$} & \multirow[b]{3}{*}{ Preservative } & \multicolumn{2}{|c|}{ Early yield $^{2}$} & \multicolumn{2}{|c|}{ Total yield } & \multirow{2}{*}{\multicolumn{2}{|c|}{$\begin{array}{l}\text { Nutsedge } \\
\left(\text { no. } / \mathrm{m}^{2}\right)\end{array}$}} \\
\hline & & No. & $\mathrm{Wt}$ & No. & $\mathrm{Wt}$ & & \\
\hline & & (no./ha) & $\left(\mathrm{kg} \cdot \mathrm{ha}^{-1}\right)$ & (no./ha) & $\left(\mathrm{kg} \cdot \mathrm{ha}^{-1}\right)$ & 19 Apr. & 30 May \\
\hline paper/LO ${ }^{y}$ & none & $5,140 \mathrm{a}$ & $56,100 \mathrm{a}$ & $8,380 \mathrm{a}$ & $84,800 \mathrm{a}$ & $0 \mathrm{a}$ & $0 \mathrm{a}$ \\
\hline paper/SO ${ }^{x}$ & none & $3,240 \mathrm{a}$ & $31,070 \mathrm{a}$ & $5,980 \mathrm{a}$ & $58,100 \mathrm{a}$ & $0 \mathrm{a}$ & $0 \mathrm{a}$ \\
\hline paper/SO & $\mathrm{ZnO}, 2.5 \%$ & $4,420 \mathrm{a}$ & $47,500 \mathrm{a}$ & $7,540 \mathrm{a}$ & $75,500 \mathrm{a}$ & $0 \mathrm{a}$ & $0 \mathrm{a}$ \\
\hline paper/SO & $\mathrm{ZnO}, 5.0 \%$ & $3,360 \mathrm{a}$ & $38,000 \mathrm{a}$ & $6,350 \mathrm{a}$ & $66,200 \mathrm{a}$ & $0 \mathrm{a}$ & $0 \mathrm{a}$ \\
\hline paper/LO & Znborate, $3.3 \%$ & $5,020 \mathrm{a}$ & 48,900 a & $7,780 \mathrm{a}$ & $72,500 \mathrm{a}$ & $0 \mathrm{a}$ & $0 \mathrm{a}$ \\
\hline paper/LO & $\mathrm{ZnO}, 3.3 \%$ & $5,260 \mathrm{a}$ & $53,400 \mathrm{a}$ & $8,850 \mathrm{a}$ & $84,900 \mathrm{a}$ & $0 \mathrm{a}$ & $0 \mathrm{a}$ \\
\hline Polyethylene & none & $3,830 \mathrm{a}$ & $41,500 \mathrm{a}$ & $7,410 \mathrm{a}$ & $74,000 \mathrm{a}$ & $0.10 \mathrm{~b}$ & $1.3 \mathrm{~b}$ \\
\hline
\end{tabular}

${ }^{2}$ From first harvest only (June 4).

${ }^{\mathrm{y}} \mathrm{LO}=$ linseed oil with cobalt 2-ethylhexanoate $(0.02 \% \mathrm{Co})$, carbon black $(1.5 \%)$.

${ }^{\mathrm{x}} \mathrm{SO}=$ soybean oil with cobalt 2 -ethylhexanoate $(0.02 \% \mathrm{Co})$, carbon black $(1.5 \%)$.

Table 6. Degradation ratings of mulches just below soil line of buried tuck for 2002 trial.

\begin{tabular}{llccccc}
\hline \multirow{2}{*}{$\begin{array}{l}\text { Mulch } \\
\text { type }\end{array}$} & \multicolumn{5}{c}{$\begin{array}{l}\text { Mulch degradation rating } \\
\text { (days after application) }\end{array}$} \\
\cline { 3 - 7 } & Preservative & 14 & 22 & 32 & 39 & 55 \\
\hline Paper/LO & None & $1.0 \mathrm{a}$ & $3.5 \mathrm{a}$ & $3.8 \mathrm{ab}$ & $3.8 \mathrm{ab}$ & $4.0 \mathrm{a}$ \\
Paper/SO $^{\mathrm{x}}$ & None & $1.0 \mathrm{a}$ & $3.8 \mathrm{a}$ & $4.0 \mathrm{a}$ & $4.0 \mathrm{a}$ & $4.0 \mathrm{a}$ \\
Paper/SO & ZnO, $2.5 \%$ & $1.0 \mathrm{a}$ & $3.3 \mathrm{a}$ & $3.8 \mathrm{ab}$ & $3.8 \mathrm{ab}$ & $4.0 \mathrm{a}$ \\
Paper/SO & ZnO, $5.0 \%$ & $1.0 \mathrm{a}$ & $3.3 \mathrm{a}$ & $3.5 \mathrm{ab}$ & $3.8 \mathrm{ab}$ & $3.8 \mathrm{a}$ \\
Paper/LO & Znborate, $3.3 \%$ & $1.0 \mathrm{a}$ & $3.8 \mathrm{a}$ & $3.8 \mathrm{ab}$ & $3.8 \mathrm{ab}$ & $4.0 \mathrm{a}$ \\
Paper/LO & ZnO, 3.3\% & $1.0 \mathrm{a}$ & $2.3 \mathrm{~b}$ & $3.3 \mathrm{~b}$ & $3.3 \mathrm{~b}$ & $4.0 \mathrm{a}$ \\
Polyethylene & None & $1.0 \mathrm{a}$ & $1.0 \mathrm{c}$ & $1.0 \mathrm{c}$ & $1.0 \mathrm{c}$ & $1.0 \mathrm{~b}$ \\
\hline
\end{tabular}

${ }^{2}$ Rating scale: 1 = no visible sign of degradation, $2=$ mulch beginning to soften but still intact, $3=$ initial degradation visible with small tears or holes in mulch, 4 = significant degradation of mulch, nearly $50 \%$ of tuck area degraded, some detachment of paper from buried tuck, $5=$ nearly $100 \%$ of buried tuck area degraded, pieces of mulch cannot be separated from soil in tuck area, mulch on top of bed detached from tuck area.

${ }^{y} \mathrm{LO}=$ linseed oil with cobalt 2-ethylhexanoate $(0.02 \% \mathrm{Co})$, carbon black $(1.5 \%)$.

${ }^{\mathrm{x}} \mathrm{SO}=$ soybean oil with cobalt 2-ethylhexanoate $(0.02 \% \mathrm{Co})$, carbon black $(1.5 \%)$. appeared more rapid than in the previous two seasons, with some mulch detachment from the buried tuck area occurring by $55 \mathrm{~d}$ (rating 4). This did not seem to be a problem, however, as the plant vines and remaining buried tuck kept the mulch in place. The more rapid degradation may have been due to the smaller amounts of oils used for coating in the 2002 trial ( $\approx 80 \%$ add-on) versus the 2000 and 2001 trials $(\approx 100 \%$ add-on) or perhaps some differences in weather. Previous work has shown that degradation rates in soil increased as the amount of oil coating was decreased (Shogren, 2000). Paper coated with soybean and linseed oil degraded at similar rates while paper coated with linseed oil containing $3.3 \%$ zinc oxide was slower to degrade early in the season. Zinc oxide is known to have moderate fungicidal activity (Trotz and Pitts, 1981).

In summary, vegetable oil coated paper mulches were applied using the same equipment as for polyethylene with only occasional tearing. Similar yields of watermelon were obtained for polymerized vegetable oil coated kraft paper and polyethylene mulches over 3 years of trials in Florida. The paper mulch blocked the growth of nutsedge while the polyethylene did not. This should help lessen the requirement for fumigation, especially methyl bromide which is currently being phased out in the U.S. The coated paper mulches begin to degrade significantly after 40 to $60 \mathrm{~d}$, but this was long enough for one crop cycle. Coatings containing linseed oil and $\mathrm{ZnO}$ tended to have slower degradation than those made with soybean oil and no preservative.

Problems with the oil coated paper mulches include oil on farm equipment, variability in degradation rates, lifetime of just one crop and higher initial costs than polyethylene mulch. The amount of surface oil on the surface of the mulch was minimized by wiping with a rubber blade but some oil would still get on surfaces of application equipment. This can be removed before it hardens with a cloth and alcohol. Alternatively, coatings made from epoxidized soybean oil and a curing agent such as citric acid can be rapidly thermally cured as the paper is being rolled, thus eliminating the oiliness problem (Shogren, 1999). There will probably always be variation in mulch degradation rates due to change in soil types, microorganism levels, temperature and rainfall. A margin for error in which degradation begins in earnest after cropping is finished would be desirable. There are certainly more effective fungicides than $\mathrm{ZnO}$, which could be used, perhaps only on the edges of the mulch, to further slow degradation. Alternatively, a more highly unsaturated, slower degrading oil like linseed or tung could be used along the edges while cheaper soybean oil could be used in the center. Recent work on the degradation of ESO-CA coated paper has shown that it would last for 20 weeks or two cropping seasons (Shogren, unpublished results). Finally, the price of polyethylene mulch is typically $\$ 250$ to $\$ 370 /$ ha compared with a cost of a polymerized oil-coated paper mulch of perhaps $\$ 610 /$ ha or more. This is offset by the elimination of the approximate $\$ 250 /$ ha cost of removal and 
disposal of polyethylene mulch. Thus, such a biodegradable mulch might appeal more to smaller farmers growing high value crops and in areas of the country where disposal of plastic mulch is especially difficult.

\section{Literature Cited}

Albregts, E.E. and C.M. Howard. 1972. Comparison of polyethylene and polyethylene-coated biodegradable paper mulches on strawberry. HortScience 7:568-569.

Anderson, D.F., M. Garisto, J. Bourrut, M.W. Schonbeck, R. Jaye, A. Wurzberger, and R. DeGregorio. 1995. Evaluation of a paper mulch made from recycled materials as an alternative to plastic film mulch for vegetables. J. Sustain. Agr. 7:39-61.

Brault, D., K.A. Stewart, and S. Jenni. 2002a. Optical properties of paper and polyethylene mulches used for weed control in lettuce. HortScience 37:87-91.

Brault, D., K.A. Stewart, and S. Jenni. 2002b. Growth, development and yield of head lettuce cultivated on paper and polyethylene mulch. HortScience 37:92-94.

Everett, P.H. 1972. Evaluation of paper and polyethylene-coated paper mulches and fertilizer rates for tomatoes. Proc. Fla. State Hort. Soc 84:124-128.

Hochmuth, B. and G. Hochmuth. 1994. Responses of pepper and watermelon to paper and polyethylene mulches in two spring seasons in north Florida. Proc. Fla. State Hort. Soc. 107:102-105.

LeClaire, J. 2002. The pros of plasticulture. The Grower 35:22-24.

Olsen, J.K. and R.K. Gounder. 2001. Alternatives to polyethylene mulch film-a field assessment of transported materials in capsicum (Capsicum annuum L). Austral. J. Expt. Agr. 41:93-103.

Rangarajan, A. 2000. Paper mulch: Can it replace plastic? http:--www.hort.cornell.edu-commercialvegetables.

Rivise, C.W. 1929. Mulch paper. Paper Trade J. 89:55-57.

Schut, J.H. 2001. Mulch film goes high-tech. Plastics Technol. (Nov.):44-47.

Shogren, R.L. 2000. Biodegradable mulches from renewable resources. J. Sustain. Agr. 16:33-47.

Shogren, R.L. 1999. Preparation and characterization of a biodegradable mulch: Paper coated with polymerized vegetable oils. J. Appl. Polymer Sci. 73:2159-2167.

Trotz, S.I. and J.J. Pitts. 1981. Industrial antimicrobial agents, p. 223-253. In: H.F. Mark, D.F. Othmer, C.G. Overberger, and G.T. Seaborg (eds.). Encyclopedia of chemical technology, $3^{\text {rd }}$ ed. vol 13. J. Wiley \& Sons, New York.

Vandenberg, J. and H. Tiessen. 1972. Influence of wax-coated and polyethylene-coated paper mulch on growth and flowering of tomato. HortScience 7:464-465. 